\section{Dietary patterns and risk of oral and pharyngeal cancer: a case-control study in Rio de Janeiro, Brazil}

\author{
Padrões dietéticos e câncer oral e de faringe: \\ um estudo caso-controle no Rio de Janeiro, Brasil
}

\author{
${ }^{1}$ Escola Nacional de Saúde \\ Pública Sergio Arouca \\ Fundação Oswaldo Cruz, \\ Rio de Janeiro, Brasil. \\ 2 Faculdade de Saúde \\ Pública, Universidade de \\ São Paulo, São Paulo, Brasil. \\ Correspondence \\ R. J. Koifman \\ Departamento de \\ Epidemiologia e Métodos \\ Quantitativos em Saúde, \\ Escola Nacional de Saúde \\ Pública Sergio Arouca, \\ Fundação Oswaldo Cruz. \\ Rua Leopoldo Bulhões 1480, \\ Rio de Janeiro, $R J$ \\ 21041-210, Brasil. \\ jorger@ensp.fiocruz.br
}

\begin{abstract}
The study investigated the association between dietary patterns and oral cancer as part of a Latin American multicenter hospital-based casecontrol study, and included 210 incident cases of oral cancer and 251 controls. Dietary data were collected using a Food Frequency Questionnaire (FFQ). Factor analysis was used to define dietary patterns, which were categorized into terciles. Odds ratios (OR) with 95\% confidence intervals (95\%CI) were calculated using unconditional multiple logistic regression. The patterns "prudent", characterized mainly by vegetables and fruits, and "traditional", by rice, and pulses showed an inverse association with oral cancer for the higher tercile, respectively, $O R=0.44$; 95\%CI: 0.25-0.75, $p$ value for trend ( $p^{\text {tend }}$ ) $=0.03$; $O R=0.53 ; 95 \% C I: 0.30-0.93, p^{\text {tend }}=0.06$. The "snacks pattern" was not associated with oral cancer. Besides the protective effect of a diet rich in vegetables and fruit, our data suggest that the traditional Brazilian diet, consisting mostly of rice and beans, may improve protection against oral cancer.
\end{abstract}

Mouth Neoplasms; Feeding Behavior; Food Consumption
Ana Lucia Araujo de Toledo 1

Rosalina Jorge Koifman 1

Sergio Koifman 1

Dirce Maria Lobo Marchioni 2

\section{Introduction}

Oral and pharyngeal cancer, grouped together, represent the sixth most common cancer in the world 1 . The annual estimated incidence is around 275,000 for oral and 130,300 for pharyngeal cancers excluding nasopharynx, with twothirds of these cases occurring in developing countries 1 . There is a wide geographical variation (approximately 20-fold) in the incidence of this cancer, and parts of Latin America and the Caribbean (including Brazil, Uruguay and Puerto Rico) are characterized by high incidence rates for oral cancer (excluding lip) 1. In Brazil, excluding skin cancer, oral and pharynx cancer represent the fifth incidence of cancer in men and the seventh in women. The incidence rates ranged from 2.9/100,000 in Belém, Pará State (1996-1998) to 7.6/100,000 in São Paulo (1997-1998) 2. The most recent Brazilian National Cancer Institute (INCA) estimates for Rio de Janeiro State are 1,510 new cases for men and 520 for women ${ }^{3}$. Most are squamous cell carcinomas that develop after exposure to carcinogens such as tobacco and alcohol 4. Oral and pharyngeal cancer involves complex causality, but available evidences suggest that environmental factors are driving the geographic patterns 5 .

The role of diet in the etiology of oral and pharyngeal cancer remains unresolved. A recent revision concluded that consumption of non-starchy vegetables, fruits, and foods containing carote- 
noids probably protect against these cancers but available evidence is still inconsistent for other dietary components ${ }^{6}$. Dietary patterns refer to the concept of "total" diet, thereby transcending the traditional focus on individual foods or nutrients common in nutritional epidemiology and overcoming the limitations associated with this approach.

Dietary patterns are measured using two general strategies: (1) empirical methods (a posteriori) use data aggregation and reduction procedures to generate patterns based upon dietary intakes as they are actually consumed; and (2) theoretical methods (a priori) employ extant nutrition knowledge of healthy diets to generate "optimal" diets, usually by creating a composite measure of total dietary quality. The utilization of both methods has gained increasing popularity in the past decade and the literature has burgeoned in recent years 7,8,9. The main technique used in the " $a$ posteriori" approach is the analysis of principal components and subsequent factor analysis 10 . In factor analysis, instead of arbitrarily adopting a diet indicator, data objectively point towards how the measurements aggregate 11 .

The analysis of dietary patterns may help to show the influence of diet on risk of oral cancer. Thus, the present study was aimed at investigating associations between dietary patterns and oral cancer.

\section{Methods}

The present hospital-based case-control study, conducted in Rio de Janeiro, Brazil, was part of an international study carried out in Latin America about oral and pharynx cancer and coordinated by the International Agency for Research on Cancer (IARC) developed in Brazil, Argentina and Cuba. The sample size was estimated considering a type I error of $5 \%$, a prevalence of exposure estimated at $10 \%$ among controls and an estimate of relative risk (odds ratio - OR) of at least 2.1, with a statistical power of $80 \%$. Thus, the estimated size in each participating center was 200 cases and 200 controls. Between 1999 and 2003, 249 patients were recruited to the study, of whom 210 accepted to participate and were histologically confirmed incident cases of oral cavity, oropharynx and hypopharynx cancer cases (median age: 56.2 years). Cases were recruited from all patients without previous treatment in Head and Neck Services of INCA located in Rio de Janeiro, and were required to be living in the Rio de Janeiro Metropolitan Area for at least one year. Subjects included cases of cancer classified as International Classification of Diseases (ICD-10) codes
C00 to C14 (oral cavity and oropharynx), with the exception of cases classified as C00.0, C00.1, and C00.2 (cancer of the external lip), and C11 (cancer of the nasopharynx). The latter were excluded based on evidence in the literature that cancers in these sites do not share the same risk factors 12 . From 263 invited controls, 251 (median age: 55.8 years) were from patients admitted to two public hospitals in the Rio de Janeiro city, due to conditions unassociated with risk factors for oral cavity and pharynx cancer, and 251 (median age: 55.8 years) agreed to participate. These conditions included digestive tract diseases (21.6\%), genitor urinary tract diseases (14.9\%), and external causes (33\%), among others. Controls were paired to cases by sex and age (in five-year intervals) according to the expected distribution of cases (frequency pairing). Controls were required to have no past or present history of actual or suspected oral cavity or pharynx cancer.

Written consent was obtained from both cases and controls. The study was approved by the Research Ethics Committees of all participating medical sites and Oswaldo Cruz Foundation (FIOCRUZ), as well as by the National Human Research Ethics Committee of the Brazilian Ministry of Health (CONEP).

\section{Data collection}

Information on lifestyle, smoking, and alcohol intake was obtained, using a standardized openended questionnaire developed by the IARC. All contacts and interviews with cases and controls were carried out by trained interviewers who were not blinded to the patient status as case or control, but had no knowledge of the study hypothesis.

\section{Dietary data}

Dietary information was collected using a semiquantitative Food Frequency Questionnaire (FFQ) developed by the IARC. The validity and reproducibility coefficients, estimated for the study conducted in São Paulo, presented a median value between 2003 and 2004 of 0,39 and 0,35 respectively 13 . The FFQ list contained 27 foods, food groups, or preparations. Study subjects were asked to inform their average weekly intake frequency, in the previous year, before the emergence of disease symptoms, for each item in the FFQ. This was an open question, allowing variables to be treated as continuous. 


\section{Other data}

Smoking was measured by considering the subject's lifetime smoking experience. Smoking experience was defined as the cumulative exposure to the number of packs of cigarettes consumed per day: tobacco in packs vs. years of exposure. The consumption of cigarettes, cigars and pipe tobacco was considered. One cigarette was considered as corresponding to one gram of tobacco. One cigar corresponds to four cigarettes, and one filling of pipe tobacco to three cigarettes 14 . Mean daily consumption cigarette packs was thus established, and this value was multiplied by the number of years for which the subject had been a smoker. For alcohol consumption, we considered mean daily alcohol intake in grams. For this, the consumption of alcoholic beverages reported by the subject was first transformed into grams of alcohol. The following conversion factors to grams of alcohol per liter of alcoholic drink were used: beer, 40g; wine, 96g; cachaça (sugarcane spirit), 328g; and liqueurs, $240 \mathrm{~g}$. Birth place, categorized according to the Brazilian regions and education level (illiterate, complete elementary school, high school, college) were reported by the patients.

\section{Statistical analysis}

Factor analysis was used to identify dietary factors or combinations of foods consumed by the study sample. Principal component analysis was used for the extraction of the factors. Factor loadings were analyzed after orthogonal rotation using the varimax method 11,15. Factor loadings of more than 0.25 were considered as significantly contributing to the factor. Factor scores for each component retained were calculated for cases and controls 11. Factor scores were categorized into terciles based on the distribution of the control population.

\section{Statistical modeling}

To determine the associations between dietary factors and oral cancer, odds ratios (OR) and 95\% confidence intervals $(95 \% \mathrm{CI})$ were calculated using unconditional logistic regression models.

For each derived factor the OR was adjusted by all other factors and by sex, age (five age groups), smoking (pack-years), alcohol consumption (g/L/day), and schooling (illiterate, elementary, high school, and college education). The linear trend was assessed by entering into the model the terciles of the dietary patterns scores as continuous variables. Potential interactions between the dietary factors and smoke and alcohol consumption were tested, including a multiplicative term in the model, but no joint effect was observed.

All analyses were performed using Stata for Windows 98/95/NT software (Stata Corp., College Station, U.S.A.).

\section{Results}

The mean age was 55.2 years (standard deviation $-\mathrm{SD}=9.9$ ) for cases and 55.5 (SD = 11.21) for controls. The distribution of years of schooling was similar for the two groups. Compared to cases, a major proportion of the controls never smoked and never consumed alcohol (Table 1).

The sample was adequate for factor analysis $(\mathrm{KMO}=0.669)$. The factor analysis identified three patterns that accounted for $33 \%$ of the total variance (Table 2). Factor loadings higher than 0.25 , marked in bold, most contributed to each factor. The first pattern, named "prudent”, presented important contributions from vegetables and raw vegetables, fruit, dairy products, potato, fish and yogurt. The second pattern, named "snacks" had significant contributions from bread, butter, cheese, pork, sandwich meat, egg and sweets and dessert, in parallel with negative values for fruits poultry, carrots, citrus fruit and brassica. The third factor was named "traditional" since rice and pasta and pulses contributed with very high loadings to the factor ( 0.81 and 0.79 respectively), besides beef and potatoes.

Inverse associations with oral cancer were observed for the third tercile of the factors "prudent" $(\mathrm{OR}=0.44 ; 95 \% \mathrm{CI}: 0.25-0.75)$ and "traditional" (OR $=5.3$; 95\%CI: 0.30-0.93), after adjusting for controlling variables, and a significant inverse trend were observed for higher consumption of the "prudent" and "traditional" diets ( $\mathrm{p}=0.002$ and $\mathrm{p}=0.029$, respectively). "Snacks" showed positive associations with oral cancer (2nd tercile: OR = 1.33; 95\%CI: 0.77-2.31; 3rd tercile: $\mathrm{OR}=1.25$; 95\%CI: 0.73-2.15; $\mathrm{p}_{\text {trend }}=0.36$ ), although not statistically significant (Table 3 ).

\section{Discussion}

Three dietary patterns ("prudent", "snacks" and "traditional") have been identified in this study towards factor analysis. The "prudent" pattern, characterized by fruit and vegetables intake, and the "traditional", related to the most commonly eaten items in the traditional Brazilian diet, namely rice and beans, were inversely associated to oral cancer. 
Description of the study population used in factor analysis of dietary patterns and risk of oral and pharyngeal cancer. Rio de Janeiro, Brazil, 1999-2003.

\begin{tabular}{|c|c|c|c|c|c|}
\hline \multirow[t]{2}{*}{ Variables } & \multicolumn{2}{|c|}{ Cases $(n=210)$} & \multicolumn{2}{|c|}{ Controls $(n=251)$} & \multirow[t]{2}{*}{$\mathrm{p}$-value $\left(\chi^{2}\right)$} \\
\hline & $\mathrm{n}$ & $\%$ & $\mathrm{n}$ & $\%$ & \\
\hline \multicolumn{6}{|l|}{ Sex } \\
\hline Male & 171 & 81.43 & 193 & 76.89 & 0.14 \\
\hline Female & 39 & 18.57 & 58 & 23.11 & \\
\hline \multicolumn{6}{|l|}{ Age (years) } \\
\hline $23-40$ & 8 & 5.64 & 18 & 3.81 & \\
\hline $40+50$ & 52 & 24.08 & 59 & 24.76 & 0.66 \\
\hline $50+60$ & 73 & 33.19 & 80 & 34.76 & \\
\hline $60+70$ & 58 & 26.90 & 66 & 27.62 & \\
\hline $70 \vdash 79$ & 19 & 10.20 & 28 & 9.05 & \\
\hline \multicolumn{6}{|l|}{ Years of schooling * } \\
\hline Illiterate & 33 & 15.79 & 28 & 11.16 & \\
\hline Complete elementary school & 154 & 73.68 & 186 & 74.10 & 0.17 \\
\hline High school & 17 & 8.13 & 22 & 8.76 & \\
\hline College & 5 & 2.39 & 15 & 5.98 & \\
\hline \multicolumn{6}{|l|}{ Smoking (pack-years) } \\
\hline 아-1 & 18 & 8.60 & 89 & 35.50 & \\
\hline $1-25$ & 43 & 20.5 & 58 & 23.10 & 0.00 \\
\hline $25 \mid-50$ & 77 & 36.7 & 66 & 26.30 & \\
\hline$\geq 50$ & 72 & 34.3 & 38 & 15.10 & \\
\hline \multicolumn{6}{|c|}{ Mean alcohol consumption (g/L/day) } \\
\hline Non-drinker & 25 & 11.90 & 94 & 37.45 & \\
\hline $0.01-40$ & 15 & 7.14 & 11 & 4.38 & \\
\hline $40+120$ & 12 & 35.29 & 22 & 8.76 & 0.02 \\
\hline $120 \mid-160$ & 13 & 6.19 & 12 & 4.78 & \\
\hline$\geq 160$ & 145 & 69.05 & 112 & 44.62 & \\
\hline \multicolumn{6}{|l|}{ Birth place } \\
\hline North & 1 & 0.50 & 2 & 0.80 & 0.86 \\
\hline Northeast & 43 & 20.40 & 62 & 24.70 & \\
\hline Middle-west & 0 & 0.00 & 1 & 0.40 & \\
\hline Southeast & 159 & 76.80 & 176 & 70.10 & \\
\hline South & 2 & 1.00 & 6 & 2.40 & \\
\hline Foreign & 5 & 2.40 & 4 & 1.60 & \\
\hline
\end{tabular}

* One case missing information.

In a recent systematic review carried out by the World Cancer Research Fund (WRFC) the evidence on the probable protector effect of fruit and vegetable consumption to oral cancer was highlighted 6 . A meta-analysis, including 15 case-control studies and 1 cohort study, revealed that daily consumption of one portion of either fruits or vegetables was associated with a $50 \%$ risk reduction of oral and pharynx cancer 16. Franco et al. 17, based on a case-control study conducted in Brazil, reported a significant protective effect for consumption of carotene-rich vegetables and citric fruits, but not for green vegetables in general. The cancer preventive effect of fruit and vegetables might be related to micronutrients, such as $\mathrm{C}, \mathrm{E}$ and A vitamins, and phytochemical action in the tumor cells 18,19 . Retinoids prevent tumoral promotion and progression in various ways: they sequester free radicals, thus limiting their production, by the activation of cellular differentiation processes, stimulate the synthesis of glycoproteins which are cellular adhesion and growth mediators as well as hormonal receptors and stimulators of the immune system. The $\mathrm{C}$ vitamin anti-oxidative action either occurring following lycopen 
Table 2

Matrix of factor loadings for cases and controls participating in the study. Rio de Janeiro, Brazil, 1999-2003.

\begin{tabular}{|c|c|c|c|c|}
\hline \multirow[t]{3}{*}{ Variables } & \multicolumn{3}{|c|}{ Factors } & \multirow[t]{3}{*}{ Communality } \\
\hline & 1 & 2 & 3 & \\
\hline & Prudent & Snacks & Traditional & \\
\hline Raw vegetable & 0.59 & 0.07 & 0.05 & 0.36 \\
\hline Citrus fruit & 0.54 & 0.05 & -0.01 & 0.29 \\
\hline Carrot & 0.52 & -0.18 & 0.07 & 0.31 \\
\hline Brassica & 0.52 & -0.04 & -0.03 & 0.27 \\
\hline Tomato & 0.51 & 0.08 & 0.13 & 0.29 \\
\hline Apple & 0.49 & -0.11 & 0.05 & 0.26 \\
\hline Juice & 0.49 & 0.08 & -0.01 & 0.24 \\
\hline Milk & 0.42 & 0.10 & -0.11 & 0.20 \\
\hline Cheese & 0.40 & 0.36 & -0.32 & 0.39 \\
\hline Banana & 0.40 & 0.13 & 0.24 & 0.24 \\
\hline Potato & 0.38 & 0.12 & 0.33 & 0.27 \\
\hline Fish & 0.34 & -0.01 & 0.18 & 0.15 \\
\hline Yogurt & 0.25 & 0.11 & -0.11 & 0.09 \\
\hline Butter & 0.13 & 0.68 & 0.09 & 0.49 \\
\hline Bread & 0.11 & 0.66 & 0.04 & 0.45 \\
\hline Pork & -0.05 & 0.46 & -0.09 & 0.22 \\
\hline Sweet and dessert & 0.19 & 0.45 & 0.08 & 0.24 \\
\hline Sandwich meat & 0.09 & 0.43 & -0.26 & 0.26 \\
\hline Egg & -0.07 & 0.42 & 0.09 & 0.19 \\
\hline Poultry & 0.07 & -0.25 & -0.06 & 0.07 \\
\hline Corn & 0.00 & 0.19 & 0.03 & 0.04 \\
\hline Manioc & 0.05 & 0.18 & 0.07 & 0.04 \\
\hline Rice and pasta & -0.01 & 0.13 & 0.81 & 0.67 \\
\hline Pulse & -0.07 & 0.23 & 0.79 & 0.68 \\
\hline Beef & 0.19 & 0.04 & 0.43 & 0.22 \\
\hline \% explained variance & 11.51 & 8.47 & 7.72 & - \\
\hline$\%$ cumulative variance & 11.51 & 19.97 & 27.69 & - \\
\hline
\end{tabular}

Table 3

Odds ratio (OR) and $95 \%$ confidence intervals $(95 \% \mathrm{Cl})$ for oral and pharyngeal cancer, obtained using multiple non-conditional logistic regression, in terciles for food groups defined a posteriori by factor analysis. Rio de Janeiro, Brazil, 1999-2003.

\begin{tabular}{|c|c|c|c|c|c|}
\hline Factors & $\begin{array}{l}\text { Terciles of } \\
\text { scores }\end{array}$ & $\begin{array}{l}\text { Cases: } \\
\text { controls }\end{array}$ & $\begin{array}{l}\text { Crude OR } \\
(95 \% \mathrm{Cl}) \text { * }\end{array}$ & $\begin{array}{l}\text { Adjusted OR } \\
(95 \% \mathrm{Cl})^{\star \star}\end{array}$ & Trend *** \\
\hline \multirow[t]{3}{*}{ Prudent } & $1^{\text {st }}$ & $111: 83$ & 1.00 & 1.00 & 0.002 \\
\hline & $2^{\text {nd }}$ & $55: 84$ & $0.53(0.34-0.84)$ & $0.70(0.42-1.17)$ & \\
\hline & $3 r d$ & $36: 84$ & $0.34(0.21-0.57)$ & $0.44(0.25-0.75)$ & \\
\hline \multirow[t]{3}{*}{ Snacks } & 1 st & $62: 83$ & 1.00 & 1.00 & 0.365 \\
\hline & $2^{\text {nd }}$ & $70: 84$ & $1.25(0.76-2.03)$ & $1.33(0.77-2.31)$ & \\
\hline & 3 rd & $76: 84$ & $1.38(0.85-2.25)$ & $1.25(0.73-2.15)$ & \\
\hline \multirow[t]{3}{*}{ Traditional } & 1 st & $75: 83$ & 1.00 & 1.00 & 0.029 \\
\hline & $2^{\text {nd }}$ & $74: 84$ & $0.86(0.54-1.37)$ & $0.89(0.53-1.52)$ & \\
\hline & 3 rd & $50: 84$ & $0.68(0.42-1.11)$ & $0.53(0.30-0.93)$ & \\
\hline
\end{tabular}

* Univariate;

** Adjusted for sex, age, smoking and alcohol consumption and schooling;

$\star \star \star$ Linear trend, adjusted for sex, age, smoking, alcohol consumption and schooling. 
(a tomato flavonoid) or citrus fruits, fruit juices and raw vegetable intake, yield to prevent tumor promotion 19,20. In our study, citrus fruits showed a marked contribution to the prudent factor. According to Jané-Salas et al. 20, phytochemicals found in cruciferous vegetables are sources of isothiocyanates, which can inhibit tumor initiation as a consequence of reducing the impact of carcinogens, and modulating the biotransformation of enzymes involved in heterocyclic aromatic amines.

The "traditional" pattern characterized by rice, beans and meat consumption, was inversely associated with oral cancer. Similar finding were observed in a study conducted in São Paulo and it was hypothesized that it might be due to the practice of consuming regular meals of this traditional mixture 21 . The type of carbohydrate could influence the amount of short-chain fatty acids produced, and starch has been associated with an increased production of butyrate 19, which could induce an inhibitory effect of oral carcinoma cell proliferation 20. Grain intake, mainly beans, represents an important component of the "traditional" pattern. However, information about its association with oral cancer is limited. Grains and derivates are enriched of fiber and selenium, a phytochemical associated with tumor inhibition 6,19,20. Similar to what has been reported elsewhere 21 , the "snacks" pattern, including bread, sandwiches and side dishes, did not reveal an association with the studied outcome. Such findings can either result from the combined consumption of diet items associated with oral cancer (such as industrialized meats) or those not associated (dairy products, for example). Dairy products are rich in calcium, but there is no evidence that this nutrient is associated with oral and pharynx cancer, even considering its acknowledged role in the progression of cells through the cell cycle 16 .

Toporcov et al. 22 reported findings from a case control study conducted in São Paulo that indicated as risk factors the habitual intake of foods rich in animal and saturated fat: pork meat, soup, cheese, bacon and fried food and a protective effect of non-cooked butter or margarine. In the present study, the second pattern, "snacks", was characterized by the intake of cheese, butter and milk. This fact reinforces the advantages of studying patterns of diet, since food items that enhance risk may be consumed at the same time as the ones considered protective. Identification of combined dietary items that diminish the risk of cancer may be useful to organize policies towards implementing changes in dietary habits among population sub-groups deserving special nutritional care.
Other studies have also used factor analysis to investigate oral and pharynx cancer 21,23. Both have identified similar patterns, related to fruit and vegetables consumption, but just one 23 revealed an inverse association with cancer risk, as observed in our study in which the protective effect of this factor was seen in the highest consumption category.

The current study was a hospital-based casecontrol investigation. Studies of this type are frequently criticized as being susceptible to information and selection bias. Information bias may be generated when case subjects are searching their memories more thoroughly than control subjects and when patients tend to invoke a suspected cause of their disease more often than controls. However, we believe this criticism applies more to population-based case-control studies than to hospital-based case-control studies, because in the latter design both cases and controls are ill and they are both being interviewed in health care settings 24 . Selection bias may be generated because only a fraction of all cases in the underlying population are included and controls may represent a different segment of the underlying population in comparison with cases. In our study, a relatively high proportion of controls presented digestive illness. However, the absence of significant selection bias in the current study is supported by the argument that the two established causes of carcinoma of the oral cavity (namely tobacco smoking and consumption of alcoholic beverages) clearly were demonstrated in the current study. In fact, data collection of smoking and alcohol, the most important risk factors for oral and pharynx cancer 6, was carried out in detail in our study, allowing a quite precise ascertainment of such exposures throughout the subject's life. Furthermore, an important bias in the recall of food intake is unlike in the current study, as dietary hypotheses were unknown for both the interviewer and the participant. Besides, only incident cases were invited to participate, and we asked about food intake one year before the diagnosis, similar to other studies 6,26 .

Other variables influencing the pattern of dietary item consumption, such as socio-economic level 27,28 , were considered in the analysis, with education being used as proxy of the former. Other potential limitation was the lack of control for oral health, as poor oral hygiene seems to cause additional cancer risks 29 . As low socio-economical status is also associated with poor oral hygiene conditions, which is an acknowledged risk factor for oral cancer ${ }^{30}$, we adjusted the analysis for educational level, as a proxy variable, in a attempt to control this effect, despite the fact that 
residual confounding might persist. Genetic susceptibility is another important related condition to the studied tumors 31 , but was not considered in the present study.

The intake of a given food may be highly correlated with the intake of other foods, as well as to individual lifestyle. Theoretically, this could be modeled statistically, with adjustment for confounding variables. However, it is difficult to judge how adequate such adjustments are. The use of the multivariate analysis technique reduces the possibility that statistically signifi- cant results might be obtained by chance. Other advantages are the transformation of correlated variables into non-correlated variables, and the reduction of the number of explanatory variables to be used in subsequent analyses 21 .

In summary, we investigated the contributions of diet to oral and pharynx carcinogenesis using factor analysis, and two of the identified dietary patterns ("prudent" and "traditional") were associated with a protective effect on the risk of oral cancer.

\section{Resumo}

Investigou-se a associação entre padrões de dieta e câncer oral, como parte de um estudo multicêntrico latino-americano caso-controle de base hospitalar e incluiu 210 casos incidentes e 251 controles. Dados de consumo alimentar foram coletados por Questionário de Freqüência de Consumo Alimentar (QFCA). Análise fatorial identificou padrões alimentares, que foram categorizados em tercis. Calculou-se odds ratio (OR) com intervalo de 95\% de confiança (IC95\%) por regressão logística múltipla não condicional. Os padrões "prudente", caracterizado em maioria por frutas e vegetais, e o padrão tradicional, por arroz e feijão, apresentaram associação inversa com o câncer oral para o mais elevado tercil, respectivamente: $O R=0,44$ IC95\%: 0,25-0,75, valor de $p$ de tendência ( $\left.p^{\text {tend }}\right)=0,03$; $O R=0,53 ;$ IC95\%: 0,30-0,93, ptend $=0,06$. O padrão "lanches" não foi associado ao câncer oral. Além da proteção ao câncer oral conferida por dieta rica em vegetais e frutas, nossos dados sugerem que a dieta "tradicional" brasileira contendo em sua maioria arroze feijão pode oferecer proteção ao câncer oral.

Neoplasias Bucais; Comportamento Alimentar; Consumo Alimentar

\section{Contributors}

All the authors participated in the article conception, data analysis and interpretation, article write-up, critical revision and approval of the final version for publication.

\section{Acknowledgments}

The authors would like to thank the Brazil Higher Education Consortia Program (CAPES) for its financial support during Ana Lucia Araujo de Toledo's doctoral studies. This study received financial support from the International Agency for Research on Cancer (IARC). 


\section{References}

1. Ferlay J, Pisani P, Parkin DM. GLOBOCAN 2002: cancer incidence, mortality and prevalence worldwide. IARC Cancer Base (2002 estimates). Lyon: IARC Press; 2004.

2. Instituto Nacional de Câncer. Câncer no Brasil: dados dos registros de base populacional. http:// www.inca.gov.br/regpop/2003/ (accessed on 13/ Dec/2008).

3. Instituto Nacional de Câncer. Estimativa 2008: incidência de cancer no Brasil. http://www.inca.gov. br/estimativa/2008/ (accessed on 15/Aug/2009).

4. Argiris A, Karamouzis MV, Raben D, Ferris RL. Head and neck cancer. Lancet 2008; 371:1695-709.

5. Wünsch-Filho V. The epidemiology of oral and pharynx cancer in Brazil. Oral Oncol 2002; 38: 737-46.

6. World Cancer Research Fund. Food, nutrition, physical activity and the prevention of cancer: a global perspective. Atlanta: World Cancer Research Fund; 2007.

7. Hoffmann K, Schulze MB, Schienkiewitz A, Nöthlings $\mathrm{U}$, Boeing $\mathrm{H}$. Application of a new statistical method to derive dietary patterns in nutritional epidemiology. Am J Epidemiol, 2004; 159:935-44.

8. Willett W. Nutritional epidemiology: monographs in epidemiology and biostatistics. 2nd Ed. v. 30. New York: Oxford University Press; 1998.

9. Hu FB. Dietary pattern analysis: a new direction in nutritional epidemiology. Curr Opin Lipidol 2002; 13:3-9.

10. Trichopoulos D, Lagiou P. Dietary patterns and mortality. Br J Nutr 2001; 85:133-4.

11. Hair JF, Rolph EA, Ronald LT, William CB. Multivariate data analysis with readings. $4^{\text {th }}$ Ed. New Jersey: Prentice Hall; 1995.

12. Lo KW, To KF, Huang DP. Focus on nasopharyngeal carcinoma. Cancer Cell 2004; 5:423-8.

13. Matarazzo HCZ, Marchioni DML, Figueiredo RAO, Villar BS, Eluf Neto J, Wünsch Filho V. Reprodutibilidade e validade do questionário de freqüência de consumo alimentar utilizado em estudo casocontrole de câncer oral. Rev Bras Epidemiol 2006; 9:316-24.

14. International Agency for Research on Cancer. Tobacco smoking. Lyon: International Agency for Research on Cancer; 1986. (IARC Monographs on the Evaluation of the Carcinogenic Risk of Chemicals to Humans, 38).

15. Kim J-o, Mueller CW. Factor analysis: statistical methods and practical issues. Beverly Hills: Sage Publications; 1978.

16. Pavia M, Pileggi C, Nobile CG, Angelillo IF. Association between fruit and vegetable consumption and oral cancer: a meta-analysis of observational studies. Am J Clin Nutr 2006; 83:1126-34.
17. Franco EL, Kowalski LP, Oliveira BV, Curado MP, Pereira RN, Silva ME, et al. Risk factors for oral cancer in Brazil: a case-control study. Int J Cancer 1989; 43:992-1000.

18. Chainani-Wu N. Diet and oral, pharyngeal, and esophageal cancer. Nutr Cancer 2002; 44:104-26.

19. Rafter J, Govers M, Martel P, Pannemans D, PoolZobel B, Rechkemmer G, et al. PASSCLAIM: dietrelated cancer. Eur J Nutr 2004; 43 Suppl 2:II47-84.

20. Jané-Salas E, Chimenos-Küstner E, López-López J, Roselló-Llabrés X. Importance of diet in the prevention of oral cancer. Med Oral 2003; 8:260-8.

21. Marchioni DML, Fisberg RM, Góis Filho JF, Kowalski LP, Carvalho MB, Abrahão M, et al. Dietary patterns and risk of oral cancer: a case-control study in Sao Paulo, Brazil. Rev Saúde Pública 2007; 41:1926.

22 Toporcov TN, Antunes JL, Tavares MR. Fat food habitual intake and risk of oral cancer. Oral Oncol 2004; 40:925-31.

23. De Stefani E, Boffetta P, Ronco AL, Correa P, Oreggia F, Deneo-Pellegrini H, et al. Dietary patterns and risk of cancer of the oral cavity and pharynx in Uruguay. Nutr Cancer 2005; 51:132-9.

24. MacMahon B, Trichopoulos D. Epidemiology: principles and methods. 2nd Ed. Boston: Little, Brown and Company; 1996.

25. Soler M, Bosetti C, Franceschi S, Negri E, Zambon P, Talamini R, et al. Fiber intake and the risk of oral, pharyngeal and esophageal cancer. Int J Cancer 2001; 91:283-7.

26. De Stefani E, Deneo-Pellegrini H, Mendilaharsu M, Ronco A. Diet and risk of cancer of the upper aerodigestive tract: I. Foods. Oral Oncol 1999; 35:17-21.

27. Sichieri R. Dietary patterns and their associations with obesity in the Brazilian city of Rio de Janeiro. Obes Res 2002; 10:42-8.

28. Hu FB, Rimm E, Smith-Warner SA, Feskanich D, Stampfer MJ, Ascherio A, et al. Reproducibility and validity of dietary patterns assessed with a foodfrequency questionnaire. Am J Clin Nutr 1999; 69:243-9.

29. Marques LA, Eluf Neto J, Figueiredo RAO, Góis Filho JF, Kowalski LP, Carvalho MB, et al. Oral health, hygiene practices and oral cancer. Rev Saúde Pública 2008; 42:471-9.

30. Guha N, Boffetta P, Wünsch Filho V, Eluf Neto J, Shangina O, Zaridze D, et al. Oral health and risk of squamous cell carcinoma of the head and neck and esophagus: results of two multicentric casecontrol studies. Am J Epidemiol 2007; 166:1159-73.

31. Choi S, Myers JN. Molecular pathogenesis of oral squamous cell carcinoma: implications for therapy. J Dent Res 2008; 87:14-32.

Submitted on 14/Apr/2009

Final version resubmitted on 28/Oct/2009

Approved on 03/Nov/2009 